\title{
KLINIKINIAI FAKTORIAI, SĄLYGOJANTYS ODONTOGENINĖS KILMĖS CELIULITO KOMPLIKAVIMĄSI
}

\author{
Gintaras Janužis ${ }^{1}$, Saulius Andruškevičius ${ }^{2}$, Viltė Medzevičiūtè ${ }^{2}$ \\ ${ }^{1}$ Lietuvos sveikatos moksly universiteto Medicinos akademijos \\ Veido ir žandikauliu chirurgijos klinika, \\ ${ }^{2}$ Lietuvos sveikatos moksly universiteto Medicinos akademijos Medicinos fakultetas
}

Raktažodžiai: odontogeniniai pūlynai, komplikacijos, klinikiniai faktoriai.

\begin{abstract}
Santrauka
Odontogeninès kilmès burnos ir veido srities infekcijos yra dažna patologija, sèkmingai gydoma veido ir žandikaulių chirurgų pasitelkiant terapinius ir chirurginius gydymo metodus. Tačiau daliai pacientų, išvengiant imuninès sistemos atsako, uždegiminis procesas, apimdamas veide ir kakle esančias fascijas bei anatominius tarpus, išplinta ị giliau esančius audinius ar organus ir sukelia gyvybei pavojingas komplikacijas: mediastinitą, meningitą, kvėpavimo taku obstrukciją, sepsị ir sepsinị šoką ir kt. [1-3]. Metodika. Atlikta retrospektyvinè pacientų, 20122016 metais gydytų LSMU KK Veido ir žandikaulių chirurgijos skyriuje dèl burnos celiulito ir absceso (TLK-10 K12.2), duomenu analizè. Pacientai tyrimui buvo atrenkami atsižvelgiant ị operacijų skaičių $(n \geq 2)$ ir sunkių komplikacijų išsivystymą gydymo eigoje: sepsis, sepsinis šokas, mediastinitas, meningitas, mirtis. Vertinta amžiaus, lyties, šalutinių ligų, ligos progreso, ligos trukmès ryšys su odontogeninès kilmès infekcijų komplikavimusi. Statistinè duomenų analizė atlikta naudojant SPSS 23.0, Medcalc 17.4.4 ir Microsoft Excel 2013 programas.

Rezultatai. Sunkios komplikacijos išsivystè 24 (40\%) pacientams: $13(54,2 \%)$ sepsių, $9(37,0 \%)$ sepsiniai šokai, 15 (62,5\%) mediastinitų, $1(4,2 \%)$ meningitas. Mirštamumas siekė 16,7\%. Nustatyta amžiaus, šalutinių ligų, susiformavusios pūlių/eksudato sankaupos bei ligos trukmès įtaka sunkių komplikacijų išsivystymui $(p<0,05)$. Apskaičiuota ligos trukmès kritinè reikšmé, prognozuojanti komplikacijų išsivystymą $73,8 \%$ atvejų, buvo 76 valandos.

Išvados. Vyresnis amžius, šalutinès ligos ir kreipimosi i gydymo ịstaigą metu nustatyta susiformavusi pūlių/eksudato sankaupa didina odontogeninès kilmès
\end{abstract}

komplikavimosi riziką. Tai tik patvirtina, kad komplikacijų išsivystymą skatina uždelstas kreipimasis ị gydymo ịstaigą, diagnostikos ir gydymo paskyrimas. Sergant ilgiau nei 3 paras, odontogeninès infekcijos komplikuojasi trims trečdaliams pacientų.

\section{Ivadas}

Gerejjant sveikatos apsaugos sistemai ir sveikatos paslaugų prieinamumui, didejjant ịstaigų, teikiančių odontologinę sveikatos priežiūrą, skaičiui, sergamumas odontogeninès kilmès uždegimais išlieka didelis. Dèl veido ir žandikauliu srities uždegimų Lietuvoje kasmet gydoma apie 15 tūkstančių gyventojų, iš kurių $3 \%$ reikalingas gydymas stacionare $[4,5]$. Remiantis 2012-2016 metų statistiniais duomenimis, Lietuvos sveikatos mokslų universiteto ligoninejje Kauno klinikose (LSMUL KK) burnos celiulito ir absceso (TLK$10 \mathrm{~K} 12.2$ ) chirurginiam gydymui kasmet stacionarizuojama apie 170 pacientų.

Odontogeninès kilmès infekcijos yra dažniausios suaugusiuju galvos ir kaklo srities patologijos, aktyviausiai pasireiškiančios trečioje gyvenimo dešimtyje. Jų atsiradimas priklauso nuo anatominių ir imuninių organizmo savybių bei patogeno virulentiškumo $[6,7]$. Dažniausiai tai polimikrobinè infekcija, sukelta Viridans grupés streptokokų, auksinio stafilokoko ir/ar anaerobinių, gramneigiamų mikroorganizmų [7-10]. Infekcijų vystymuisi sudaromos tinkamos sąlygos esant užleistoms ar netinkamai gydomoms burnos ligoms. Tyrimų duomenimis, pirminiai infekcijos ,vartai“ dažniausiai aptinkami $2-3$ - jame krūminiuose dantyse $[5,11,12]$.

Neretai ši patologija tampa iššūkiu siekiant gerų diagnostikos ir gydymo rezultatų. Ankstyvoje infekcijos stadijoje atsiradę simptomai - skausmas, patinimas ar sutrikęs prasižiojimas - būna mažai išryškejęe, todèl dažnai tinkamo gydymo paskyrimas būna pavèluotas. Nesuteikus reikiamos pagalbos, patogenas gali išplisti į bet kurị organą, sukeldamas gyvybei pavojingas būkles: sepsį, sepsinị šoką, mediastinitą, meningitą, kaverninio sinuso trombozę, smegenų abscesą ir kitas patologijas. Ivvairių autorių duomenimis, ypač pabrè- 
žiama, kad ankstyvas patologijos atpažinimas, diagnozavimas ir gydymas yra būtinas siekiant išvengti tolimesnių ligos komplikacijų ir mirties [7, 8, 13-16].

Tyrimo tikslas - nustatyti amžiaus, lyties, šalutinių ligų ir ligos trukmès ryši su odontogeninès kilmės infekcijų komplikavimusi.

\section{Metodika}

Atlikta retrospektyvinè pacientų, 2012 - 2016 metais gydytų LSMUL KK Veido ir žandikaulių chirurgijos skyriuje dèl burnos celiulito ir absceso (TLK-10 K12.2), duomenu analizè. Iš 862 pacientų išnagrinèta 60 ligos istorijų. Pacientai tyrimui buvo atrenkami atsižvelgiant ị operacijų skaičių (n $\geq 2$ ) ir sunkių komplikacijų išsivystymą gydymo eigoje: sepsis, sepsinis šokas, mediastinitas, meningitas, mirtis. Tyrimo metu renkami pacientų duomenys buvo: amžius, lytis, šalutinès ligos, kreipimosi ị gydymo įstaigą data ir laikas, ligos priežastis, radiologinių tyrimų duomenys, pirmosios operacijos data ir laikas. Statistinè duomenų analizè atlikta naudojant SPSS 23.0. Laiko intervalų kritinès reikšmès sunkioms

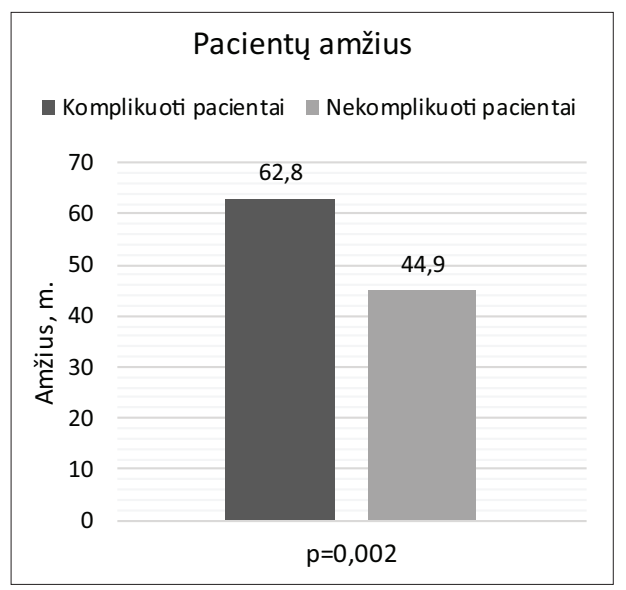

1 pav. Vidutinis pacientų amžius skirtingose grupèse

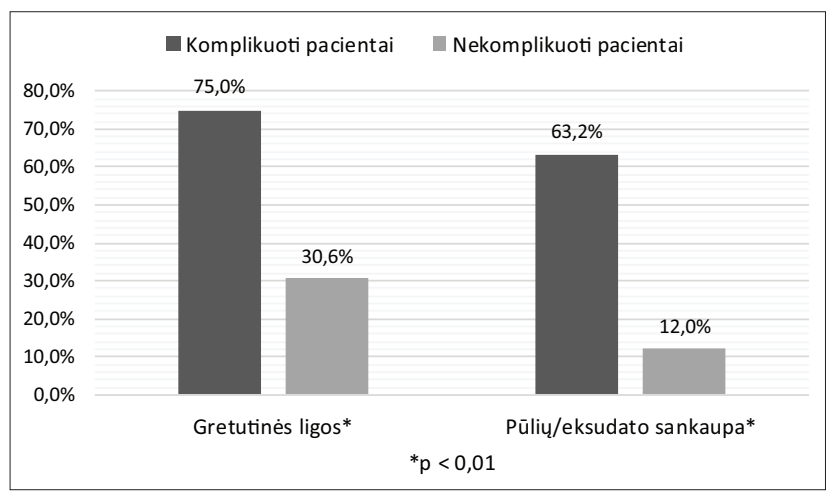

2 pav. Šalutinių ligų ir pūlių/eksudato pasiskirstymas skirtingose pacientų grupėse komplikacijoms išsivystyti vertintos naudojant ROC kreivių analizę. Rezultatai laikyti statistiškai reikšmingais, kai reikšmingumo lygmuo ( $p$ reikšmè) buvo mažesnis už 0,05 .

\section{Rezultatai}

Tiriamają imtị sudarè $41(68,3 \%)$ vyras ir $19(31,7$ $\%)$ moterų. Pacientų amžiaus vidurkis $52( \pm 21)$ metai. Dažniausiai pasitaikanti ligos priežastis - dantų kariesas ( $\mathrm{n}=36,60 \%$ ), dažniausiai pažeidžiami buvo $37-38$ krūminiai dantys ( $\mathrm{n}=19,28,3 \%) .24$ - iems (40\%) pacientams išsivystė sunkios komplikacijos: 13 (54,2\%) sepsių, $9(37,0 \%)$ sepsiniai šokai, 15 (62,5\%) mediastinitu, 1 $(4,2 \%)$ meningitas. Mirštamumas siekè $16,7 \%(\mathrm{n}=10)$.

Šalutinèmis ligomis sirgo $48,3 \%(n=29)$ pacientu, is kuriu $31,0 \%(n=9)$ vargino daugiau nei viena šalutinè patologija. Kreipimosi ị gydymo ịstaigą metu, pasitelkiant radiologinius metodus (UG, KT), buvo nustatoma, ar infekcijos vietoje yra susiformavusi pūlių/eksudato sankaupa. $25,0 \%(\mathrm{n}=15)$ pacientų buvo nustatyta susiformavusi pūlių/ eksudato sankaupa, 48,3\% $(\mathrm{n}=29)$ - jos nebuvo, 26,7 \% $(\mathrm{n}=16)$ netaikyta radiologinè diagnostika.

Ivertinus gautus duomenis, nustatytas statistiškai reikšmingas amžiaus skirtumas tarp komplikuotų ir nekomplikuotų pacientų $(62,8 \pm 21,2$ vs. $44,9 \pm 18,2 \mathrm{~m} . ; \mathrm{p}=0,002)(1$

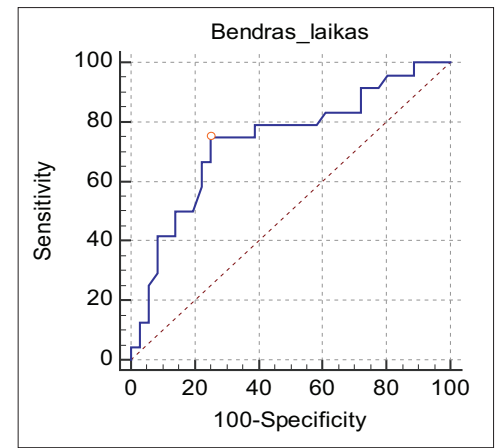

3 pav. Ryšio tarp komplikacijų ir laiko nuo simptomų atsiradimo iki operacinio gydymo kreivè

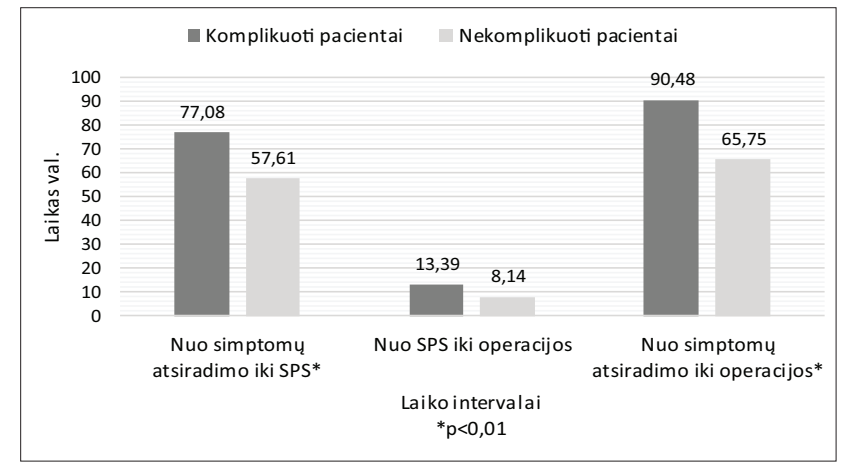

4 pav. Laiko intervalų pasiskirstymas skirtingose pacientų grupėse 
pav.). Taip pat stebėta šalutinių ligų (75,0 \% vs. $30,6 \%$; $p$ $=0,001)$ bei kreipimosi ị gydymo ịstaigą metu susiformavusios pūlių/eksudato sankaupos $(63,2 \%$ vs. $12,0 \%$; p < $0,001)$ ịtaka sunkioms komplikacijoms išsivystyti (2 pav.). Komplikacijų dažnis tarp lyčių statistiškai reikšmingai nesiskyrè $(\mathrm{p}=0,821)$.

Siekiant ịvertinti ligos trukmès įtaką sunkioms komplikacijoms išsivystyti, sirgimo laikas buvo suskirstytas $i$ tris intervalus: nuo simptomu atsiradimo iki kreipimosi i skubios pagalbos skyriu (SPS), nuo SPS iki operacijos ir nuo simptomu atsiradimo iki operacijos. Vidutinis laikas nuo simptomų atsiradimo iki kreipimosi į SPS buvo 65,4 $\pm 30,7$ val., nuo SPS iki intervencijos $-10,2 \pm 15,5$ val., nuo simptomu atsiradimo iki operacijos $-75,6 \pm 32,1$ val. Nustatyta, kad pacientų, patyrusių sunkias komplikacijas, laikotarpis nuo simptomu atsiradimo iki SPS buvo ilgesnis nei pacientų, išvengusių komplikacijų $(77,08 \pm 30,44$ val. vs. 57,61 $\pm 28,63$ val.; $p=0,007)$. Ligos trukmè nuo simptomu atsiradimo iki operacinio gydymo buvo statistiškai reikšmingai ilgesnè pacientų, kuriems išsivystè sunkios komplikacijos $(90,48 \pm 32,35$ vs. $65,75 \pm 28,16$; $\mathrm{p}=$ 0,003). Laikas nuo kreipimosi i SPS iki operacijos nesiskyrè tarp komplikuotu ir nekomplikuotu pacientu grupių ( $\mathrm{p}=$ 0,259) (4 pav.). Naudojant ROC kreivių statistinę analizę, apskaičiuota kritinè laiko nuo simptomų atsiradimo iki operacinio gydymo reikšmè, leidžiančios numatyti sunkių komplikacijų išsivystymą. Nustatyta, kad operacinio gydymo neskyrus daugiau nei 76 valandas, sunkių komplikacijų išsivystymas tikètinas $73,8 \%$ atvejų $(\mathrm{AUC}=0,738$; jautrumas 75,00; specifiškumas 75,00; $p<0,001$ ) (3 pav.).

\section{Rezultatų aptarimas}

Atlikto tyrimo rezultatai sutampa su kitų autorių, nagrinèjusių sunkių odontogeninių infekcijų komplikavimąsi, studijų duomenimis. Šiame tyrime, kaip ir kitose publikacijose, lyties įtaka sunkioms komplikacijoms išsivystyti nenustatyta [17-19]. Vertinant amžiaus ir šalutinių ligų ryšį su odontogeninès kilmès infekcijų komplikavimusi, apskaičiuoti duomenys nurodo, kad komplikuoti pacientai buvo vyresnio amžiaus, jie dažniau sirgo šalutinèmis ligomis, lyginant su išvengusiais sunkių komplikacijų. Atsižvelgiant ị ligonių amžių, kaip ị rizikos veiksnį, panašios išvados pateikiamos ir kitose publikacijose [18], tačiau sutinkami ir priešingi rezultatai, nenurodantys statistiškai reikšmingo amžiaus skirtumo tarp komplikuotų ir nekomplikuotų pacientų. $[6,17,19]$ Šalutinių ligų įtaka komplikacijoms pasireikšti pateikiama ir kitų autorių darbuose [17-20]. Galima pastebèti, kad literatūroje didžiausias dėmesys, kaip šalutinei ligai, yra skiriamas cukriniam diabetui. Ši patologija išskiriama dẻl didelio sergamumo bei imuninès sistemos sutrikimų, atsirandančių esant nepakankamai glikemijos kontrolei. Mūsų tyrime cukrinio diabeto, kaip izoliuoto veiksnio, ittaka nebuvo tiriama dèl nedidelès pacientų imties.
Apskaičiuota, kad kreipimosi ị gydymo ịstaigą metu rasta susiformavusi pūlių/eksudato sankaupa, lyginant su infiltrato nebuvimu, didina infekcijos plitimo tikimybę. 2015 m. Prancūzijoje N. Alotaibi su kolegomis atliktas tyrimas pateikia tokias pačias išvadas [21].

Apžvelgus mokslo literatūrą, tyrimų, vertinančių ligos trukmès koreliaciją su sunkių komplikacijų išsivystymu, nebuvo pastebèta. Siame moksliniame darbe apskaičiuota statistiškai reikšminga ligos trukmès ịtaka odontogeninès kilmès infekcijų komplikavimuisi. Taip pat nustatyta, kad ligos trukmè 76 valandos yra jautriausia reikšmè, leidžianti numatyti sunkių komplikacijų išsivystymą $74 \%$ atvejų. Vertinant ligos trukmę, tikslinga atsižvelgti ị nespecifinius, ligos pradžioje mažai ryškius simptomus, kurie, priklausomai nuo sergančiojo, gali lemti skirtingą laikotarpi nuo simptomų atsiradimo iki kreipimosi ị gydymo ịstaigą. Todèl apskaičiuota kritinè ligos trukmè turètų būti vertinama kaip subjektyvus rodmuo, padėsiantis ịtarti padidejusią sunkių komplikacijų išsivystymo riziką.

\section{Išvados}

Vyresnis amžius, šalutinės ligos ir kreipimosi ị gydymo ịstaigą metu nustatyta susiformavusi pūlių/eksudato sankaupa didina odontogeninès kilmès komplikavimosi riziką. Tai tik patvirtina, kad komplikacijų išsivystymą skatina uždelstas kreipimasis ị gydymo įstaigą, diagnostikos ir gydymo paskyrimas. Sergant ilgiau nei 3 paras, odontogeninès infekcijos komplikuojasi trims trečdaliams pacientų.

\section{Literatūra}

1. Brito TP, Hazboun IM, Fernandes FL, Bento LR, Zappelini CE, Chone CT. et al. Deep neck abscesses: study of 101 cases. Braz J Otorhinolaryngol 2016 May 5.

2. Guzmán-letelier M, Crisosto-jara C, Diaz-ricouz C, Pe-arrochadiago M, Pe-arrocha-oltra D. Severe odontogenic infection: An emergency. Case report. J Clin Exp Dent 2017 Feb 1;9(2):e319e324.

3. Yang W, Hu L, Wang Z, Nie G, Li X, Lin D. et al. Deep neck infection: a review of 130 cases in Southern China. Medicine (Baltimore) 2015 Jul;94(27):e994.

https://doi.org/10.1097/MD.0000000000000994

4. Rastenienè R, Pūrienė A, Aleksejūniene J. Veido ir žandikaulių srities odontogeninių infekcijų gydymo apimtys Lietuvoje. Sveikatos mokslai, 25(2):111-6.

5. Rastenienė R, Aleksejūnienè J, Pūrienè A. Determinants of length of hospitalization due to acute odontogenic maxillofacial infections: a 2009-2013 retrospective analysis. Med Princ Pract 2015;24(2):129-35.

https://doi.org/10.1159/000370073

6. Mathew GC, Ranganathan LK, Gandhi S, Jacob ME, Singh I, Solanki M. et al. Odontogenic maxillofacial space infections at a tertiary care center in North India: a five-year retrospective study. Int J Infect Dis 2012 Apr;16(4):e296-302. 
https://doi.org/10.1016/j.ijid.2011.12.014

7. Shah A, Ramola V, Nautiyal V. Aerobic microbiology and culture sensitivity of head and neck space infection of odontogenic origin. Natl J Maxillofac Surg 2016 Jan-Jun;7(1):56-61. https://doi.org/10.4103/0975-5950.196126

8. Sobottka I, Wegscheider K, Balzer L, Böger RH, Hallier O, Giersdorf I. et al. Microbiological analysis of a prospective, randomized, double-blind trial comparing moxifloxacin and clindamycin in the treatment of odontogenic infiltrates and abscesses. Antimicrob Agents Chemother 2012 May;56(5):2565-9. https://doi.org/10.1128/AAC.06428-11

9. Chunduri NS, Madasu K, Goteki VR, Karpe T, Reddy H. Evaluation of bacterial spectrum of orofacial infections and their antibiotic susceptibility. Ann Maxillofac Surg 2012 Jan;2(1):4650. 28

10. Kityamuwesi R, Muwaz L, Kasangaki A, Kajumbula H, Rwenyonyi CM. Characteristics of pyogenic odontogenic infection in patients attending Mulago Hospital, Uganda: a cross-sectional study. BMC Microbiol 2015 Feb 25;15:46. https://doi.org/10.1186/s12866-015-0382-z

11. Zaleckas L, Rasteniene R, Rimkuviene R, Seselgyte R. Retrospective analysis of cellulitis of the floor of the mouth. Stomatologija, 2010;12(1):23-7.

12. Bahl R, Sandhu S, Singh K, Sahai N, Gupta M. Odontogenic infections: microbiology and management. Contemp Clin Dent 2014 Jul;5(3):307-11. https://doi.org/10.4103/0976-237X.137921

13. Opitz D, Camerer C, Camerer DM, Raguse JD, Menneking $\mathrm{H}$, Hoffmeister B. et al. Incidence and management of severe odontogenic infections-a retrospective analysis from 2004 to 2011. J Craniomaxillofac Surg 2015 Mar;43(2):285-9.

https://doi.org/10.1016/j.jcms.2014.12.002

14. Dalla Torre D, Burtscher D, Höfer D and Kloss F. Odontogenic deep neck space infection as life threatening condition in pregnancy. Aust Dent J 2014 Sep;59(3):375-8.

https://doi.org/10.1111/adj.12189

15. Cachovan G, Blessmann M, Schön G, Rother U, Heiland M, Stürenburg E. et al. Radiography-based score indicative for the pathogenicity of bacteria in odontogenic infections. Acta Odontol Scand 2014 Oct;72(7):530-6. https://doi.org/10.3109/00016357.2013.876553

16. Clifton TC, Kalamchi S. A case of odontogenic brain abscess arising from covert dental sepsis. Ann R Coll Surg Engl 2012 Jan;94(1):e41-3. https://doi.org/10.1308/003588412X13171221499667

17. Han X, An J, Zhang Y, Gong X, He Y. Risk Factors for life threatening complications of maxillofacial space infection. $J$ Craniofac Surg 2016 Mar;27(2):385-90. https://doi.org/10.1097/SCS.0000000000002416

18. Sakarya EU, Kulduk E, Gündoğan O, Soy FK, Dündar R, Kilavuz AE. et al. Clinical features of deep neck infection: analysis of 77 patients. Kulak Burun Bogaz Ihtis Derg 2015;25(2):102-8.

https://doi.org/10.5606/kbbihtisas.2015.76500

19. Zemplenyi K, Lopez B, Sardesai M, Dillon JK. Can progression of odontogenic infections to cervical necrotizing soft tissue infections be predicted?. Int J Oral Maxillofac Surg 2017 Feb;46(2):181-188.

https://doi.org/10.1016/j.ijom.2016.09.016

20. Bali RK, Sharma P, Gaba S, Kaur A, Ghanghas P. A review of complications of odontogenic infections. Natl J Maxillofac Surg 2015 Jul-Dec;6(2):136-43

https://doi.org/10.4103/0975-5950.183867

21. Alotaibi N, Cloutier L, Khaldoun E, Bois E, Chirat M, Salvan D. Criteria for admission of odontogenic infections at high risk of deep neck space infection. Eur Ann Otorhinolaryngol Head Neck Dis 2015 Nov;132(5):261-4.

https://doi.org/10.1016/j.anorl.2015.08.007

\section{CLINICAL FACTORS LEADING TO COMPLICATIONS OF MOUTH CELLULITE OF ODONTOGENIC ORIGIN}

G. Janužis, S. Andruškevičius, V. Medzevičiūtė

Key words: cellulite; odontogenic infections; maxillofacial infections.

\section{Summary}

Purpose. To evaluate age, sex, comorbidities and duration of the disease bond with maxillofacial infections of odontogenic origin. Methodology. A retrospective data analysis of 60 cases was conducted. Patients were selected according to the surgery due to the cellulite and abscess of the mouth (TLK - $10 \mathrm{~K} 12.2$ ), number of surgeries $(n \geq 2)$ and the development of severe complications in the course of treatment: sepsis, septic shock, mediastinitis, meningitis and death. Age, sex, comorbidities, the formation of pus/exudate abscess and duration of the disease bond with complications of maxillofacial infections of odontogenic origin. Statistical data was performed by using SPSS 23.0 Medcalc 17.4.4 and Microsoft Excel 2013 programs. Results. Difficult complications occurred for $24(40.0 \%)$ patients: $13(54.2 \%)$ sepsis, 9 (37.0\%) septic shock, $15(62.5 \%)$ mediastinitis, 1 (4.2\%) of meningitis. Mortality was $16.7 \%$. An influence of age, comorbidities, the formation of pus/ exudate abscess and duration of the disease to the development of complications was established $(\mathrm{p}<0,05)$. Estimated critical value of the duration of disease, which predicts the development of the complications, was 76 hours. Conclusions. Elderly age, comorbidities and developed pus/exudate abscess increase the risk of severe complications. The development of complications is increased by delayed hospital admission, diagnostics and treatment. Disease period of more than 3 days leads to severe complications for threequarters of the patients.

Correspondence to: saulius.andruskevicius@gmail.com

Gauta 2017-05-22 